Hal. 390 - 399

\title{
MILLENIUM DEVELOMPENT GOALS (MDGS) DAN SUSTAINABLE DEVELOPMENT GOALS (SDGS) DALAM KESEJAHTERAAN SOSIAL
}

\author{
Wahyuningsih \\ IImu Kesejahteraan Sosial. Fakultas IImu Sosial dan IImu Politik
}

\begin{abstract}
Sustainable Development Goals (SDGs) are designed as the successor of the Millennium Development Goals (MDGs) as the MDGs' goals have not been achieved by the end of 2015. The SDGs is an action plan for the humankind, the planet, and the prosperity that also aims to strengthen universal peace in a broad freedom. It exists to overcome extreme poverty as the greatest global challenge. The SDGs concept is needed as a new development framework that accommodates all the changes occur after the 2015-MDGs, especially related to the world's changes since 2000 regarding the issue of deflation of natural resources, environmental degradation, crucial climate change, social protection, food and energy security, and a more pro-poor development. MDGs aimed only for the developing countries, while SDGs have a more universal goal. The SDGs is present to replace the MDGs with better goals to face the world future challenge. It has 17 goals and 169 targets that will stimulate actions for the next 15 years, focusing on the significant areas for the humanity and the planet, i.e., the people, planet, prosperity, peace, and partnership.
\end{abstract}

Keywords: $\quad$ MDGs, SDGs, Social Welfare, Development.

\begin{abstract}
Abstrak: Sustainable Development Goals (SDGs) dirancang sebagai kelanjutan dari Millennium Development Goals (MDGs) yang belum tercapai tujuannya sampai dengan akhir tahun 2015. SDGs adalah suatu rencana aksi untuk umat manusia,planet, dan kemakmuran yang juga bertujuan untuk memperkuat perdamaian universal dalam kebebasan yang luas. SDGs ada untuk mengatasi kemiskinan yang ekstrim yang merupakan tantangan global yang paling besar.Konsep SDGs diperlukan sebagai kerangka pembangunan baru yang mengakomodasi semua perubahan yang terjadi pasca 2015-MDGsterutama berkaitan dengan perubahan situasi dunia sejak tahun 2000 berkenaan dengan isu deflasi sumber daya alam, kerusakan lingkungan, perubahan iklim yang semakin krusial, perlindungan sosial, ketahanan energi dan pangan, dan pembangunan yang lebih berpihak pada kaum miskin. Berbeda dengan MDGs yang ditujukan hanya pada negara-negara berkembang, SDGs memiliki sasaran yang lebih universal. SDGs dihadirkan untuk menggantikan MDGs dengan tujuan yang lebih memenuhi tantangan masa depan dunia. SDGs mempunyai 17 tujuan dan 169 target. Tujuan dan target tersebut akan menstimulus aksi dalam 15 tahun kedepan pada area-area yang penting bagi kemanusiaan dan planet yaitu: manusia, planet, kemakmuran, perdamaian, dan kemitraan.
\end{abstract}

Kata Kunci: MDGs, SDGs, Kesejahteraan Sosial,Pembangunan. 


\section{Pendahuluan}

Pembangunan pada hakikatnya merupakan suatu proses yang berkesinambungan antara berbagai dimensi, baik dimensi sosial, ekonomi, maupun lingkungan yang bertujuan untuk kesejahteraan masyarakat. Pembangunan yang dilaksanakan selama ini cenderung memanfaatkan sumber daya alam dengan semena-mena, tanpa memperhatikan aspek lingkungan yang ada. Akibatnya kerusakan dan pencemaran lingkungan semakin sering terjadi (Isbandi, 2005).

Dampak-dampak tersebut dapat merugikan atau mengganggu kehidupan manusia. Perhatian dunia terhadap masalah lingkungan yang terjadi sudah lama dilakukan. Dimulai dari dilaksanakannya Konferensi Tingkat Tinggi (KTT) di Stockholm, Swedia tahun 1972. Dalam konferensi tersebut dicapai kesepakatan tentang hubungan antara masalah lingkungan yang terkait dengan pembagunan berkelanjutan. Sejak saat itu konsep pembangunan yang ramah lingkungan mulai diimplementasikan dalam pelaksanaan pembangunan oleh berbagai negara. Pada tahun 2000, para pemimpin dunia menyepakati tentang 8 tujuan pembagunan global yang spesifik dan terukur yang disebut Millenium Development Goals (MDGs).

MDGs adalah tujuan dan tanggung jawab dari semua negara yang berpartisipasi dalam KTT Milenium, baik pada rakyatnya maupun secara bersama antar pemerintahan. Target yang tercakup dalam MDG sangat beragam, mulai dari mengurangi kemiskinan dan kelaparan, menuntaskan tingkat pendidikan dasar, mempromosikan kesamaan gender, mengurangi kematian anak dan ibu, mengatasi HIV/AIDS dan berbagai penyakit lainnya, serta memastikan kelestarian lingkungan hidup dan membentuk kemitraan dalam pelaksanaan pembangunan. Pencapaian tujuan dalam MDGs memiliki target waktu hingga 2015. Agenda ke depan untuk melanjutkan MDGs, dikembangkan suatu konsepsi dalam konteks kerangka/agenda pembangunan pasca 2015, yang disebut Sustainable Development Goals (SDGs).

Konsep SDGs ini diperlukan sebagai kerangka pembangunan baru yang mengakomodasi semua perubahan yang terjadi pasca 2015-MDGs (Akhir, D. J., 2015). Terutama berkaitan dengan perubahan situasi dunia sejak tahun 2000 mengenai isu deflation sumber daya alam, kerusakan lingkungan, perubahan iklim semakin krusial, perlindungan sosial, food and energy security, dan pembangunan yang lebih berpihak pada kaum miskin. Berbeda halnya dengan MDGs yang ditujukan hanya pada negara-negara berkembang, SDGs memiliki sasaran yang lebih universal. SDGs dihadirkan untuk menggantikan MDGs dengan tujuan yang lebih memenuhi tantangan masa depan dunia. 


\section{Pembahasan}

Millennium Development Goals (MDGs) atau dalam bahasa Indonesia diterjemahkan menjadi Tujuan Pembangunan Milenium, adalah sebuah paradigma pembangunan global, dideklarasikan Konferensi Tingkat Tinggi Milenium oleh 189 negara anggota Perserikatan Bangsa Bangsa (PBB) di New York pada bulan September 2000. Dasar hukum dikeluarkannya deklarasi MDGs adalah Resolusi Majelis Umum Perserikatan Bangsa Bangsa Nomor 55/2 Tangga 18 September 2000, (A/Ris/55/2 United Nations Millennium Development Goals).Semua negara yang hadir dalam pertemuan tersebut berkomitmen untuk mengintegrasikan MDGs sebagai bagian dari program pembangunan nasional dalam upaya menangani penyelesaian terkait dengan isu-isu yang sangat mendasar tentang pemenuhan hak asasi dan kebebasan.

Pemerintah Indonesia turut menghadiri Pertemuan Puncak Milenium di New York tersebut dan menandatangani Deklarasi Milenium itu. Deklarasi berisi komitmen negara masing-masing dan komunitas internasional untuk mencapai 8 buah tujuan pembangunan dalam Milenium ini (MDG), sebagai satu paket tujuan yang terukur untuk pembangunan dan pengentasan kemiskinan. Penandatanganan deklarasi ini merupakan komitmen dari pemimpin-pemimpin dunia untuk mengurangi lebih dari separuh orang-orang yang menderita akibat kelaparan, menjamin semua anak untuk menyelesaikan pendidikan dasarnya, mengentaskan kesenjangan gender pada semua tingkat pendidikan, mengurangi kematian anak balita hingga $2 / 3$, dan mengurangi hingga separuh jumlah orang yang tidak memiliki akses air bersih pada tahun 2015

Suistainable Development Goals (SDG'S) adalah singkatan atau kepanjangan dari sustainable development goals, yaitu sebuah dokumen yang akan menjadi sebuah acuan dalam kerangka pembangunan dan perundingan negara-negara di dunia. Post-2015, juga dikenal sebagai Sustainabale Development Goals (SDGs) didefinisikan sebagai kerangka kerja untuk 15 tahun ke depan hingga tahun 2030. Berbeda dengan MDGs yang lebih bersifat birokratis dan teknokratis, penyusunan butir-butir SDGs lebih inklusif melibatkan banyak pihak termasuk organisasi masyarakat sipil atau Civil Society Organization (CSO). Penyusunan SDGs sendiri memiliki beberapa tantangan karena masih terdapat beberapa butir-butir target MDGs yang belum bisa dicapai dan harus diteruskan di dalam SDGs. Seluruh tujuan, target dan indikator dalam dokumen SDGs juga perlu mempertimbangkan perubahan situasi global saat ini (Yohanna, 2015).

Sustainable Development Goals (SDGs) adalah kelanjutan dari global goals Melenium Development Goals (MDGs) yang akan berakhir tahun 2015. Secara formal, SDGs didiskusikan pertama kali pada United Nations Conference on Sustainable Development yang diadakan di Rio de Janeiro bulan Juni 2012.Dokumen SDGs disahkan pada KTT Pembangunan berkelanjutan PBB yang berlangsung di New York tanggal 25-27 
September 2015. Dalam KTT tersebut ditetapkan bahwa SDGs akan mulai diberlakukan pasca tahun 2015 sampai tahun 2030. SDGs tidak hanya berlaku untuk negara berkembang, tapi juga untuk negara-negara maju pada akhir tahun 2015.

\section{Konsep MDGs dan SDG'S}

Pembangunan era millenium yang sudah di deklarasikan, dikenal dengan Millennium Development Goals (MDGs), dan deklarasi MDGs merupakan hasil perjuangan dan kesepakatan bersama antara negara-negara berkembang dan negara maju. Negaranegara berkembang berkewajiban untuk melaksanakannya, termasuk salah satunya Indonesia di mana kegiatan MDGs di Indonesia mencakup pelaksanaan kegiatan monitoring MDGs. Sedangkan negara-negara maju berkewajiban mendukung dan memberikan bantuan terhadap upaya keberhasilan setiap tujuan dan target MDGs. MDGs akan berakhir pada 2015, namun hingga kini belum ada konsep final yang akan meneruskan program MDGs. Untuk itu, ilmuwan dan berbagai kalangan berusaha mendalami konsep Sustanable Development Goals (SDGs) sebagai penerus MDGs.

Konsep SDGs ini diperlukan sebagai kerangka pembangunan baru yang mengakomodasi semua perubahan yang terjadi pasca 2015, Millennium Development Goals (MDGs). Konsep SDGs melanjutkan konsep pembangunan Millenium Development Goals (MDGs) di mana konsep itu sudah berakhir pada tahun 2015. Jadi, kerangka pembangunan yang berkaitan dengan perubahan situasi dunia yang semula menggunakan konsep MGDs sekarang diganti SDGs.

Adapun tiga pilar yang menjadi indikator dalam konsep pengembangan SDGs yaitu, pertama indikator yang melekat pembangunan manusia (Human Development), di antaranya pendidikan, kesehatan. Indikator kedua yang melekat pada lingkungan kecilnya (Social Economic Development), seperti ketersediaan sarana dan prasarana lingkungan, serta pertumbuhan ekonomi. Sementara itu, indikator ketiga melekat pada lingkungan yang lebih besar (Environmental Development), berupa ketersediaan sumber daya alam dan kualitas lingkungan yang baik.

\section{Tujuan MDGs dan SDG'S}

Delapan tujuan MDGs yang harus di laksanakan oleh setiap negara yang mendeklarasikannya yaitu; 1) menanggulangi kemiskinan dan kelaparan, 2) mencapai pendidikan dasar untuk semua, 3) mendorong kesetaraan gender dan pemberdayaan perempuan, 4) menurunkan angka kematian anak, 5) meningkatkan kesehatan ibu, 6) memerangi HIV/AIDS, malaria dan penyakit menular lainnya, 7) memastikan kelestarian lingkungan hidup, dan 8) mengembangkan kemitraan global untuk pembangunan. Indonesia sebagai salah satu negara yang ikut dalam mendeglarasikan tujuan MDGs 
memiliki kewajiban untuk melaksanakan upaya untuk mencapai target MDGs dan memonitor perkembangan kemajuan pencapaian.

Upaya pencapaian MDGs merupakan sebuah rangkaian proses jangka panjang berkesinambungan. Hal ini bukan merupakan hal yang mudah, terutama pada saat Indonesia masih berada pada masa transisi memulihkan diri dari krisis multidimensional yang diawali dengan krisis ekonomi-moneter pada tahun 1997, menuju pemerintahan yang lebih demokratis dan melaksanakan reformasi dihampir seluruh bidang kehidupan. Hal ini membutuhkan kerjasama dari semua lapisan masyarakat mulai dari pemerintah masyarakat, dunia usaha, dunia politik, dan institusi akademis. Hal inilah yang akan di kaji dalam tulisan ini, bagaimana strategi yang dilaksanakan oleh pemerintah Indonesia dengan menjalankan program-program pembangunan masyarakat untuk mewujudkan tujuan pembangunan millennium.

Delapan Tujuan MDGs telah di jabarkan dalam target-target yang dapat diukur dan progresnya dapat dipantau dan dilaporkan dengan menggunakan indikator- indikator yang dapat diverifikasi dan diperbandingkan secara internasional. Kepada setiap negara diberikan fleksibilitas untuk menyesuaikan dan melakukan lokalisasi terhadap indicatorindikator tersebut

Tujuan SDGs antara lain : 1) Tanpa Kemiskinan, tidak ada kemiskinan dalam bentuk apapun di seluruh penjuru dunia. 2) Tanpa Kelaparan, tidak ada lagi kelaparan, mencapai ketahanan pangan, perbaikan nutrisi, serta mendorong budidaya pertanian yang berkelanjutan. 3) Kesehatan yang Baik dan Kesejahteraan Menjamin kehidupan yang sehat serta mendorong kesejahteraan hidup untuk seluruh masyarakat di segala umur. 4) Pendidikan Berkualitas, Menjamin pemerataan pendidikan yang berkualitas dan meningkatkan kesempatan belajar untuk semua orang. 5) Kesetaraan Gender, mencapai kesetaraan gender dan memberdayakan kaum ibu dan perempuan. 6) Air Bersih dan Sanitasi, menjamin ketersediaan air bersih dan sanitasi yang berkelanjutan untuk semua orang. 7) Energi Bersih dan Terjangkau, menjamin akses terhadap sumber energi yang terjangkau, terpercaya, berkelanjutan dan modern untuk semua orang. 8) Pertumbuhan Ekonomi dan Pekerjaan yang Layak, mendukung perkembangan ekonomi yang berkelanjutan, lapangan kerja yang produktif serta pekerjaan yang layak untuk semua orang. 9) Industri, Inovasi dan Infrastruktur, membangun infrastruktur yang berkualitas, mendorong peningkatan industri yang berkelanjutan serta mendorong inovasi. 10) Mengurangi Kesenjangan, mengurangi ketidaksetaraan baik di dalam sebuah negara maupun di antara negara-negara di dunia. 11) Keberlanjutan Kota dan Komunitas, membangun kota-kota serta pemukiman yang berkualitas, aman dan bekelanjutan. 12) Konsumsi dan Produksi Bertanggung Jawab, menjamin keberlangsungan konsumsi dan pola produksi.13) Aksi Terhadap Iklim, bertindak cepat untuk memerangi perubahan iklim 
dan dampaknya. 14) Kehidupan bawah laut, melestarikan dan menjaga keberlangsungan laut dan kehidupan sumber daya laut untuk perkembangan yang berkelanjutan.15) Kehidupan di Darat, melindungi, mengembalikan, dan meningkatkan keberlangsungan pemakaian ekosistem darat, mengelola hutan secara berkelanjutan, mengurangi tanah tandus serta tukar guling tanah. 16) Institusi Peradilan yang Kuat dan Kedamaian, meningkatkan perdamaian termasuk masyarakat untuk pembangunan berkelanjutan, menyediakan akses untuk keadilan bagi semua orang termasuk lembaga dan bertanggung jawab untuk seluruh kalangan. 17) Kemitraan untuk Mencapai Tujuan, Memperkuat implementasi dan menghidupkan kembali kemitraan global untuk pembangunan yang berkelanjutan.

\section{Perbedaan MDG'S DAN SDG'S}

Pada dasarnya MDGs dan SDGs punya persamaan dan kesamaan tujuan yang sama. Yakni, SDGs melanjutkan cita-cita mulia MGDs yang ingin konsen menganggulangi kelaparan dan kemiskinan di dunia. Namun, dokumen yang disepakati pimpinan dunia pada tahun 2000 tersebut habis pada tahun 2015. Para pemimpin dunia merasa agenda Millenium Development Goals perlu dilanjutkan, sehingga muncul sebuah dokumen usulan bernama sustainable development goals.

Sustainable Development Goals (SDGs) dirancang sebagai kelanjutan dari Milineum Development Goals (MDGs) yang belum tercapai tujuannya samapai pada akhir tahun 2015. SDGs adalah suatu rencana aksi untuk umat manusia ,planet dan kemakmuran. Juga tujuannya untuk memperkuat perdamaian universal dalam kebebasan yang luas selain itu untuk mengatasi kemiskinan yang ekstrim adalah tantangan global yang paling besar dan merupakan prasyarat yang tidak dapat dilanjutkan untuk pembangunan berkelanjutan (Bappenas, 2015).

Konsep SDGs ini diperlukan sebagai kerangka pembangunan baru yang mengakomodasi semua perubahan yang terjadi pasca 2015-MDGs. Terutama berkaitan dengan perubahan situasi dunia sejak tahun 2000 mengenai isu deflation sumber daya alam, kerusakan lingkungan, perubahan iklim semakin krusial, perlindungan sosial, food and energy security, dan pembangunan yang lebih berpihak pada kaum miskin. Berbeda halnya dengan MDGs yang ditujukan hanya pada negara-negara berkembang, SDGs memiliki sasaran yang lebih universal. SDGs dihadirkan untuk menggantikan MDGs dengan tujuan yang lebih memenuhi tantangan masa depan dunia. SDGs mempunyai 17 tujuan dan 169 target.tujuan dan target ini akan menstimulus aksi ke dalam limabelas tahun kedepan pada area-area yang penting bagi kemanusiaan dan planet yaitu manusia, planet, kemakmuran, perdamaian dan kemitraan. 


\section{Relevansi SDGs dengan Kesejahteraan Sosial}

Kesejahteraan Sosial adalah sistem yang terorganisir dari usaha-usaha sosial dan lembaga-lembaga sosial yang ditunjukkan untuk membantu individu atau kelompok dalam mencapai standart hidup dan kesehatan yang memuaskan, serta untuk mencapai relasi perseorangan dan sosial yang dapat memungkinkan mereka mengembangkan kemampuan-kemampuan mereka secara penuh, serta untuk mempertinggi kesejahteraan mereka selaras dengan kebutuhan- kebutuhan keluarga dan masyarakat. (Walter A. Friedlander, Dalam Whibawa dkk, 2015:29).

Kesejahteraan sosial mempunyai tujuan:

1. Mencapai kehidupan yang sejahtera dalam artian tercapaianya standart kehidupan pokok seperti sandang,perumahan, pangan, kesehatan, dan relasi -relasi social yang harmonis dengan lingkungannya.

2. Untuk mencapai penyesuain diri yang baik khususnya dengan masyarkat dilingkungannya, misalnya dengan menggali sumber-sumber, meningkatkan dan mengembangkan taqraf hidup yang memuaskan.

3. Pembangunan Kesejahteraan Sosial didefinisikan sebagai pendekatan pembangunan yang bertujuan untuk meningkatkan kualitas hidup masyarakat melalui peningkatan modal ekonomi (economic capita), Manusia (human capital), Kemasyarakatan (Society capital), dan perlindungan (security capital) secara terintegrasi dan berkesinambungan. Peningkatan modal ekonomi masyarakat adalah tubuhnya matapencaharian (livelihood) yang memungkinkan mereka memperoleh dan mengelola asset-aset finansial dan material. Dengan demikian, pada gilirannya mereka mampu memenuhi kebutuhan dasarnya sesuai dengan standar kemanusian yang layak dan berkelanjutan (Whibawa dkk, 2015:3)

Bidang usaha kesejahteraan social atau pelayanan sosial atau disebut praktik pekerjaan sosial terdiri dari berbagai cakupan yang saling terkait antara satu dengan lainnya:

1. Kesejahteraan anak dan keluarga

2. Kesejateraan remaja dan generasi remaja

3. Kesejahteraan orang lanjut usia

4. Pelayanan kesejahteraan umum

5. Pelayanan Rekreasional

6. Pelayanan Kesehatan mental

7. Pelayanan Sosial medis

8. Pelayanan Sosial bagi penyandang cacat

9. Pelayanan Sosial bagi wanita

10. Pelayanan Sosial perumahan dan lingkungan 
Perhatian pemerintah dan masyarakat secara umum terhadap perlunya standart kehidupan yang lebih baik, telah mendorong terbentuknya usaha kesejahteraan social. Pada dasarnya usaha kesejahteraan sosial merupaka suatu program untuk menjawab masalah kebutuhan masyarakat atau meningkatkan taraf hidup masyarakat. Organisasi yang menyediakan usaha kesejahteraan social atau layanan sosial disebut dengan organisasi pelayanan masyarakat (human service organisasion) atau disingkat HSO. Tujuan dari HSO antara lain:

1. Tujuan Kemanusiaan dan keadilan sosial

Tujuan ini bersumber dari gagasan ideal demokratis keadilan social dan hal ini berasal dari keyakinan bahwa setiap manusia mempunyai hak untuk mengembangkan potensi diri yang mereka miliki,

2. Tujuan yang terkait dengan pengadilan sosial

Tujuan ini berkembang berdasarkan pemahaman bahwa kelompok yang tidak diuntungkan, kekurangan ataupun tidak terpenuhi kebutuhan hidupnya akan menjadi ancaman bagi kelompok masyarakat yang sudah mapan.

3. Tujuan yang terkait dengan pembangunan sosial

Tujuan ini memprioritaskan pada program yang dirancang untuk meningkatkan produksi barang dan jasa serta berbagai sumber daya yang dapat menunjang dan memberikan sumbangan pada pembangunan ekonomi

Berdasarkan Pengertian kesejahteraan sosial, tujuan, bidan usaha dan pelayanan kesejahteraan sosial terdapat beberapa tujuan dan target dalam SDGs sejalan terutama pada (Adi, 2014):

Tujuan 1. Mengakhiri kemiskinan dalam segala bentuk dimanapun.

Tujuan 2. Mengakhiri kelaparan, mencapai ketahanan pangan dan nutrisi yang lebih baik dan mendukung pertanian berkelanjutan.

Tujuan 3. Memastikan kehidupan yang sehat dan mendukung kesejahteraan bagi semua untuk semua usia.

Tujuan 4. Memastikan pendidikan yang inklusif dan berkualitas setara, juga mendukung kesempatan belajar seumur hidup bagi semua.

Tujuan 5. Mencapai kesetaraan gender dan memberdayakan semua perempuan dan anak perempuan.

Tujuan 6. Memastikan ketersediaan dan manajemen air bersih yang berkelanjutan dan sanitasi bagi semua.

Tujuan 7. Memastikan akses terhadap energi yang terjangkau, dapat diandalkan, berkelanjutan dan modern bagi semua

Tujuan 8. Mendukung pertumbuhan ekonomi yang inklusif dan berkelanjutan, tenaga kerja penuh dan produktif dan pekerjaan yang layak bagi semua. 
Tujuan 9. Membangun infrastruktur yang tangguh, mendukung industrialisasi yang inklusif dan berkelanjutan dan membantu perkembangan inovasi

Tujuan 10. Mengurangi ketimpangan didalam dan antar Negara.

Tujuan 11. Membangun kota dan pemukiman yang inklusif, aman, tangguh dan berkelanjutan.

Tujuan 12. Memastikan pola konsumsi dan produksi yang berkelanjutan

Keselarasan SDGs dengan IImu kesejahteraan social diharapkan mampu memecahkan permasalahan social yang ada di dunia khususnya di masyarakat Indonesia. Dengan cara pengembangan keilmuannya melalui penelitian-penelitian yang bermanfaat terutama penelitian yang menjadi bidang focus SDGs yaitu Manusia, planet, kemakmuran, perdamaian, kemitraan.

\section{Kesimpulan}

Suistainable develoopment goal's (SDG'S) merupakan sebuah dokumen yang akan menjadi sebuah acuan dalam kerangka pembanggunan dan perundingan negara-negara di dunia. Dimana konsep SDG'S ini melanjutkan konsep dari MDG'S yang sudah berakhir di tahun 2015. Pada dasarnya MDG'S dan SDG's punya persaamaan dan kesamaan tujuan yang sama. Yaitu SDG'S melanjutkan cita-cita mulia dari MDG'S yang ingin menanggulangi kelaparan dan kemiskinan di dunia.

SDGs ini tidak terpisah dari MDGs, SDGs merupakan bentuk penyempurnaan MDGs. SDGs merupakan kelanjutan dari apa yang sudah dibangun pada MDGs (Millenium Development Goals). SDG's memiliki 5 pondasi yaitu manusia, planet, kesejahteraan, perdamaian, dan kemitraan yang ingin mencapai tiga tujuan mulia di tahun 2030 berupa mengakhiri kemiskinan, mencapai kesetaraan dan mengatasi perubahan iklim

\section{Saran}

Beberapa tujuan MDGs dan SDGs selaras dengan bidang usaha dan pelayanan kesejahteraan sosial sehingga keselarasan yang ada antara ketiganya dapat membantu memecahkan persoalan yang ada di masyarakat terutama untuk keberlangsungan Manusia, planet demi kelangsungan perdamaian dan kemakmuran umat manusia.

\section{Daftar Referensi}

Isbandi, Adi Rukmianto. 2005. IImu Kesejateraan Sosial dan Pekejaan Sosial.Jakarta. FISIP UI Press

Akhir, D. J. 2015.Sustainable Development Goals. Jakarta: Okezone.Com.

Bappenas.2015. Rencana Pembangunan Nasional Jangka Menengah 2015-2019. Jakarta: 
Bappenas.2015.http://www.bappenas.go.id/berita-dan-siaran-pers/berita-harian bappenas/ konsep-sdgs-kerangka-pembangunan-pasca-2015/.Retrieved November 26, 2015, from www.bappenas.go.id

Adi, Fahrudin. 2014. Pengantar Kesejahteraan Sosial. Bandung. Refika Aditama.

Wibhawa, Budhi dkk. 2015. Pengantar Pekerjaan Sosial.Bandung.Unpad Press.

Yohanna, S.2015.. Transformasi Millenium Development Goals(Mdg's) Menjadi Post 2015 Guna Menjawab Tantangan Pembangunan Global Baru. 